\title{
The Indonesian Strategy to Achieve Universal Health Coverage through National Health Insurance System: Challenges in Human Resources
}

\begin{abstract}
Atikah Adyas
Magister Program of Public Health, Universitas Mitra Indonesia, Bandar Lampung, Indonesia

Abstract

Many countries are currently trying to achieve universal health insurance coverage in order to provide health protection for their population. Indonesia has received a strong political commitment to implement national health insurance including government support to finance the poor. The implementation of comprehensive national health insurance requires human resources, each of which has a role in fighting for noble goals for the welfare of all people. This paper is taken from the experience of Indonesia and several other countries as well as guidelines that can be used in exploring the role of human resources for the success of the implementation of national health insurance.
\end{abstract}

Keywords: human resources, national health insurance, universal health coverage

Indonesia's national health insurance (NHI) system called Jaminan Kesehatan Nasional (JKN) was declared in January 2014 by the elected President, Joko Widodo. The NHI is a form of government commitment to achieving universal health coverage (UHC). This policy is a result of Indonesia's struggle since the issuance of the National Social Security System Law No. 40 of 2004.1,2 Since 2011, Indonesia has continued to develop NHI and shared experiences with other countries to move towards universal health coverage. 3,4 The current NHI implementation is being considered quite successful in achieving UHC. ${ }^{5,6}$ According to the World Health Organization (WHO), "Universal health coverage is a system in which everyone in a society can get the healthcare services they need without incurring financial hardship." WHO's Director-General, Margaret Chan, asserts that "Universal health coverage is the single most powerful concept that public health has to offer." 7 The President of the UN General Assembly, María Fernanda Espinosa Garcés, states that "If we look at the full impact-and cost-of poor health services, the case for prioritizing universal health coverage is clear." 8

Five years of running the NHI have shown Indonesia quite significant results. Comparing the statistical data provided by the National Social Security Council/Dewan

Correspondence": Atikah Adyas, Magister Program in Public Health, Universitas Mitra Indonesia, Bandar Lampung City, Lampung Province, Indonesia, E-mail: adyas_atikah@yahoo.com, Phone: +6281389139354
Jaminan Sosial Nasional (DJSN) in 2014 and 2019 on JKN coverage shows an increase from 133 million to 224 million. ${ }^{9}$ The increasing number of coverage is listed as follows 156,790,287 (2015), 171,939,254 (2016), 187,982,949 (2017), 208,054,199 (2018), and $224,149,019$ (2019). The increasing number of the NHI coverages reflects the public's expanded access to health services in Indonesia in all forms of service levels, both primary and referral services. ${ }^{10,11}$ It is also specifically highlighted that the NHI has prioritized and contributed to reducing maternal mortality by increasing access to services for pregnant women and childbirth. ${ }^{12}$ However, to achieve UHC, qualified human resources (HR) are essential for providing adequate and equitable health services in the various regions. ${ }^{13-15}$ It should be noted that the main requirement for the NHI is to be able to fulfill the right to health services for the participants by making the facilities available. The variation in the number of accesses between provinces and regions indicates the need for additional health facilities and HR. ${ }^{16,17}$

Limited HR serving the NHI participants in dominant government health facilities suggests opportunities to invite the private sector to play a role in the NHI. ${ }^{18,19}$ In addition, due to the relatively large number of participants, Social Security Administrator for Health/Badan

Received : October 22, 202

Accepted : October 30, 2021

Published: November 29, 2021 
Penyelenggara Jaminan Sosial (BPJS) Kesehatan is required to carry out reliable health-insurance business functions with HR who know health insurance both at the central level and at the regional branch level. ${ }^{19,20}$ Likewise, the ability to develop, regulate, and supervise the relatively complex NHI integrates health services with financing requires HR with knowledge of health insurance. ${ }^{21}$ The term "human resources" implies that people (along with other resources such as money, materials, and information) in an organization have capabilities to drive the organizational performance. Other terms such as "human capital" and "intellectual assets" have in common the idea that people make the difference in how an organization performs. ${ }^{22}$ This paper will discuss the three crucial HR, as actors in the NHI, who work as health service providers, NHI organizers, and regulators.

\section{The Health Service Providers: Service Quality and Cost Containment}

The main challenge of providing health insurance coverage in low-middle-income countries such as Ghana, Myanmar, and Indonesia is the unequal presence of health service providers, especially in the poor and remote areas. ${ }^{23-25}$ Special attention should be given to directing enough workforce to eastern Indonesia, considering that the number of workers and facilities is still insufficient. Another challenge for the NHI in urban areas is the high number of non-communicable diseases (NCDs) cases such as diabetes mellitus, hypertension, heart disease, and cancer that cost relatively large amounts of money. Neighboring Australia is still looking for a pattern to handle NCDs to achieve UHC by improving Primary Health Care (PHC) services. ${ }^{26}$ Although, on the one hand, Indonesia has implemented a chronic disease management program/Program Penatalaksanaan Penyakit Kronis (PROLANIS) at the PHC services, which is related to the capitation for all the NHI participants, ${ }^{27}$ this capitation payment system, unfortunately, has more time for PHC workers to serve the NHI patients. On the other hand, the public health program that must be strengthened with sufficient HR and quality services is neglected. ${ }^{28}$ Indonesia is still experiencing the problem of the high number of cases of infectious diseases such as tuberculosis and malaria.

There is a criticism of UHC efforts which have caused a decrease in the achievement of public health programs. ${ }^{29,30}$ The efficiency of public health programs, which are the responsibility of regional financing, tends to decline, resulting in poor quality of public health programs. Even a big country like the United State of America is currently debating developing UHC because low-income people cannot access quality services and chronic NCDs in the current health insurance system. ${ }^{31}$
The existence of a significant relationship between the global health security index (GHSI) and the universal health coverage index (UHCI) indicates that there must be a synergy between UHC and the public health program. ${ }^{32}$ Therefore, it is necessary to balance the use of HR to achieve UHC that is also responsible for the NHI.

The NHI must implement a service quality assurance program because participants expect satisfactory service in return. ${ }^{33,34}$ The NHI that pays for primary health facilities with the capitation method provides an opportunity to improve the quality of services, including increasing HR capacity. According to the regulation, the amount of capitation should be reviewed every two years. But it has not yet been improved, which results in low service quality. Low-middle-income countries that procure substandard essential medicines show a negative relationship indicator between service coverage and government effectiveness. While in drug services, the friendly attitude of officers, completeness of prescriptions, and drug safety information have a significant positive effect on hospital pharmacy use, ${ }^{35,36}$ factors of doctors, pharmacists, and patients have a joint impact on the availability of drugs in the NHI. ${ }^{37}$

Service quality assurance and cost control cannot stand alone. The provision of health services should think about quality by using sophisticated services and not controlling costs. The provision of health services should pay attention to the importance of health technology assessment. 38 The HR of health services must consider whether a treatment intervention uses medical devices that are not burdensome cost the money incurred but follow the therapy protocol.

\section{The National Health Insurance Organizer: Professional Work Appearance}

The systematic reviews of the NHI in several countries have found only one paper regarding health management and administration in social protection schemes, even though the implementation of the NHI requires professional HR. The NHI organizer should implement health management and administration in social protection schemes that include some key competencies: a good knowledge about the insured population, responsiveness to health needs and preferences, administration of the insured (registration, collecting contributions, information, advice, and directing patients, control of fraud, and abuse), a good understanding of health technology assessment, assessment of provider competencies (service quality and accreditation, claims management), and negotiation with providers (on volume, quality, and cost of services), and then subsequently contracting, monitoring, and controlling results, ${ }^{39} \mathrm{WHO}$ has outlined a global HR strategy for health workforce 2030 to accelerate progress toward UHC and Sustainable Development Goals 
(SDGs). The availability of health workers is said to be adequate if they are evenly distributed, accessible, and supported by the health system and have the required competencies to provide quality services that are acceptable to the population. 40

Implementing the NHI using social insurance mechanisms and the principle of prepaid care financing requires HR who understand the basics of health insurance and managed care. Selecting and collaborating with health facilities involves negotiation skills, especially while dealing with private health facilities that are expected to support government policies voluntarily. HR of the NHI organizer reviews health services to ensure that the quality of services is cost controlled. In Indonesia, the laws related to health insurance require an NHI organizer to be called BPJS Kesehatan to carry out its functions professionally and understand health insurance for all populations. The regulations require that the implementation of health insurance should be managed by HR, who have expertise in health insurance. ${ }^{41,42}$ It needs the NHI organizer to do marketing so that the public knows the benefits of the NHI to maintain those who have become participants and achieve the target of $98 \%$ of the population coverage. Although the coverage has reached around $83 \%$ of the population, many registered participants still do not know how to use the health facilities according to the standard procedures. Provision of information regarding the importance of following referral procedures must continue to be carried out to prevent public complaints, ${ }^{11} \mathrm{NHI}$ organizers need to provide counseling that preventing illness through first-level services is more efficient than referral services.

In terms of funding, the NHI has the most significant source of financing from the subsidy for the poor for carrying out social duties. Besides that, the local governments in several provinces and districts are still developing regional health insurance programs that need to accommodate the potential resources of this area so that they can be integrated with the central budget. ${ }^{43}$ The NHI HR requires considering the need for health costs that integrate regional budget and central to maximize the NHI financing. The NHI funding must be managed with financial management that can be accounted for transparently free from corruption, so it requires HR with good mental and moral behavior. The implementation of the NHI function requires supervision to prevent violations and misuse of intentions, which in terms of fraud insurance. ${ }^{44,45}$ However, the human resources responsible for overseeing NHI's business operations are primarily low in knowing that $\mathrm{NHI}$ is integrating financing with health services. ${ }^{46}$

Indonesia is not alone. Most countries that are developing UHC face human resource challenges. For instance, Bangladesh, which is experiencing a shortage of
HR. ${ }^{47}$ Japan, which has achieved UHC since 1961, is still improving its quality human resource system. ${ }^{48}$ To achieve UHC, Iran uses the Global Health Workforce Alliance (GHWA) framework and has identified that every country should engage critical stakeholders, including government, professional bodies, and academics, to formulate appropriate strategies to overcome human resources for health $(\mathrm{HRH})$ challenges. Iran developed eleven strategies related to education and training for new disciplines, balancing universities based on manpower needs, and enrolling local students from disadvantaged areas. ${ }^{49}$

All possible efforts should be made to improve HR and enable them to perform their work professionally, even though these resources are limited. Especially in this era of digitalization, the NHI requires the ability of HR who are technology literate to accelerate services not only at the center but also to the nearest community service level. Some professional organizations participate in supporting the implementation of the NHI. ${ }^{50}$ It is necessary to conduct a series of training and certification competency tests. But only a few universities incorporate health financing and insurance into the education curriculum. ${ }^{51}$

\section{The Regulators: National Health Insurance Arrangements}

Regulators are responsible for NHI arrangements. Many countries fail in the inclusiveness of coverage due to a lack of a legal framework to support informal sector funding and a lack of political will to address these failures. ${ }^{52,53}$ Regulations in health financing determine the sustainability of the NHI. The Philippine NHI has successfully obtained major achievements by expanding population coverage by using an earmarked revenue source (Sin Tax). ${ }^{54}$ Ghana is considering adopting a broad taxbased approach to cover all citizens and persons with legal residence. ${ }^{55}$ Thailand started its efforts to achieve UHC in 2002. Policies that prioritize the tax financing system face challenges because there are still many poor people. Developing the existing primary care system in Thailand has the most significant potential for UHC sustainability by shifting from the traditional role of PHC in providing primary disease-based care to being the first contact in an integrated care system prioritized by the national health budget. ${ }^{56}$ Indonesia NHI receives subsidy allocation funds for the poor from the Ministry of Health budget based on data released by the Ministry of Social Affairs. The Ministry of Finance determines the number of funds allocated for subsidies and contributions, determined through a presidential decree. However, HR upgrading the unified database/Basis Data Terpadu (BDT) from the village to district level still encounter obstacles in terms of invalid targeting, which will have an impact on the amount of the NHI budget. ${ }^{57}$ 
Table 1. Three Categories of Human Resources in National Health Insurance (Role and Function)

\begin{tabular}{|c|c|c|c|}
\hline \multirow{2}{*}{ Role and Function } & \multicolumn{3}{|c|}{ Three Categories of Human Resources in NHI } \\
\hline & Health Service Provider & Organizer & Regulator \\
\hline Responsibility & Service quality and cost containment & Professional work appearance & $\mathrm{NHI}$ arrangements \\
\hline Duty & Carry out NHI cooperation & Health management and administration & Political and policy support \\
\hline Role & $\begin{array}{l}\text { Balance of individual health services } \\
\text { and public health program }\end{array}$ & Achieving targeted coverage & Harmonizing and synchronizing regulation \\
\hline Relation in HR & Adhere to protocol therapy & $\begin{array}{l}\text { Competent in health insurance concept } \\
\text { and management }\end{array}$ & Explore the potential of private HR \\
\hline $\begin{array}{l}\text { Relation in local/regional } \\
\text { government }\end{array}$ & Equal distribution and incentive & $\begin{array}{l}\text { Availability of health facilities and } \\
\text { infrastructure }\end{array}$ & Lobbying central and regional funding \\
\hline
\end{tabular}

Notes: NGI = National Health Insurance, $\mathrm{HR}=$ Human Resource

As with the nonprofit nature of social insurance, implementing the NHI to achieve UHC requires government policy support. As a human right, UHC requires consistency and authoritative and practical guidance. 58 The UHC can be accomplished only through the law. Advancing the right to health through UHC requires that health services adhere to five fundamental values of being (1) universally accessible, (2) equitable, (3) affordable, (4) high quality, and (5) cost-effective. A comprehensive national health law should ensure that everyone in the country is eligible for the whole package of health services, medicines, and vaccines. ${ }^{59}$ Four principles-the legal right to health, government financing, efficient spending, and financial protection of vulnerable populations-are significantly more vital in national medicines policies. ${ }^{60}$ The UHC is a human right that requires a national program-oriented human rights-based approach as a consistent, authoritative, and practical guide to support countries on the path to achieving UHC.

As a regulator and the legislature, the government is the main legitimate duty bearer under international human rights law is working together with civil society towards UHC. ${ }^{61}$ A study in Rwanda found that the commitment to expanding health insurance coverage was made possible by a dominant political settlement. 62 Human resource gaps are a major concern for successful UHC. A study in South Africa recommends that the NHI demonstrate a multistakeholder structure with an integrated plan that considers the health system as a whole. 63 Bilateral cooperation in medical education, such as that carried out by the South African government, shows that doctors have adequate skills to meet the challenges of UHC. ${ }^{64}$ China has taken a long-term task toward UHC that started in 2010. Continued political support is the most important and enabling factor, and clear political will can make UHC achievement a more country-led process. These two critical factors are increasing health financing and the investment from both government and private sector. 65 The idea of UHC is very much in a po- litical fashion. HR needs skills to carry out political lobbying both at the central and regional levels. ${ }^{50,66}$ The NHI requires that HR who sit in the bureaucracy should understand the importance of policies for the continuity of the NHI for social welfare (Table 1).

\section{Conclusion}

The National Health Insurance (NHI) towards universal health coverage (UHC) needs to be qualified and motivated human resources (HR) at the central level and the regional level. Three key actors reflect the needs of human resource specifications: health service providers, organizers, and regulators. The health service provider works to ensure service quality and that costs are controlled. The organizer functions to perform a task professionally. The first two actors can work well in a clear and coordinated setting where the regulator makes consistent policy and regulatory arrangements. The need for human resources globally is expected to grow significantly in the coming decades due to population growth, changing epidemiology, and new technologies. The human resource must constantly update their knowledge, skills, and attitude. Designing strategies for specific training and education are important to reflect the broader nature of the NHI toward UHC.

\footnotetext{
Abbreviations

NHI: National Health Insurance; JKN: Jaminan Kesehatan Nasional; UHC: Universal Health Coverage; WHO: World Health Organization; UN: United Nation; DJSN: Dewan Jaminan Sosial Nasional; HR: Human Resources; BPIS: Badan Penyelenggara Jaminan Sosial; NCD: Non-communicable Diseases; PROLANIS: Program Penatalaksanaan Penyakit Kronis; PHC: Primary Health Care; GHSI: Global Health Security Index; UHCI: Universal Health Coverage Index; SDGs: Sustainability Development Goals; GHWA: Global Health Workforce Alliance; HRH: Human Resources for Health; PAMJAKI: Perkumpulan Ahli Manajemen Jaminan dan Asuransi Kesehatan Indonesia; BDT: Basis Data Terpadu.
} 


\section{Ethics Approval and Consent to Participate}

Not Applicable

\section{Competing Interest}

The author declares that there are no significant competing financial, professional, or personal interests that might have affected the performance or presentation of the work described in this manuscript.

\section{Availability of Data and Materials}

The data that support the findings of this study were available from NHI. Restrictions apply to the availability of these data, which were used under license for this study. Data are available from the authors upon reasonable request and with the permission of NHI.

\section{Authors' Contribution}

AA carried out the literature survey, analyzed the data, and wrote the manuscript. Conveniently, by having only one author, there were no decisions to make regarding author order or corresponding authorship.

\section{Acknowledgment \\ Not Applicable}

\section{References}

1. Agustina R, Dartanto T, Sitompul R, Susiloretni KA, Suparmi, Achadi EL, et al. Universal health coverage in Indonesia: concept, progress, and challenges. Lancet. 2018; 393 (10166): 75-102.

2. Thabrany H. Jaminan kesehatan nasional. Edisi 2. Jakarta: PT Rajagrafindo Persada; 2014.

3. Adyas A, Mukti G, Ansyori A, Mulyadi D. Indonesia's health insurance landscape and the options for expanding coverage to the informal sector: how to deal with multiple schemes in moving toward universal coverage. In Kenya: Presented in the Joint Learning Network for Universal Health Coverage (JLN) Workshop on Coverage; 2011.

4. Adyas A, Kristanto J, Darmawan ES, Mukti AG. Merancang kebijakan paket manfaat - UHC. Pelajaran dari enam negara (terjemahan). The joint Learning Network for Universal Health Coverage: Universitas Indonesia; 2019.

5. Oldistra F, Machdum SV. Analisis perencanaan kebijakan jaminan kesehatan nasional dari aspek kepesertaan di Kementrian PPN / BAPPENAS. Jurnal Ilmu Kesejahteraan Sosial. 2020; 21 (1): 63-86.

6. Nugraheni WP, Mubasyiroh R, Hartono RK. The influence of Jaminan Kesehatan Nasional (JKN) on the cost of delivery services in Indonesia. PLoS One. 2020; 15 (7): 1-16.

7. Lagomarsino G, Garabrant A, Adyas A, Muga R, Otoo N. Moving towards universal health coverage: health insurance reforms in nine developing countries in Africa and Asia. The Lancet. 2012; 380: 933-43.

8. Assembly of the United Nations President of the 73rd session. Making the United Nations relevant to all people general. In Universal Health Coverage; 2019.

9. Badan Penyelenggaran Jaminan Sosial Kesehatan. Statistik JKN 20142018. Dewan Jaminan Sosial Nasional. 2019; 53: 1689-99.

10. Fitrian W, Sofiatin Y, Afriandi I. Pola pelayanan penderita hipertensi peserta JKN di FKRTL Provinsi Jawa Barat tahun 2015-2016 (Service patterns for JKN participants with hypertension in FKRTL West Java Province year 2015-2016). JKKI. 2021; 10 (3)

11. Yusuf E, Awwaliyah I. The implementation of Indonesian national health insurance programme: how satisfied were the insured participants and the healthcare providers? Journal of Consumer Sciences. 2018; 3 (2): 27-42.

12. Anindya K, Lee JT, McPake B, Wilopo SA, Millett C, Carvalho N. Impact of Indonesia's national health insurance scheme on inequality in access to maternal health services: a propensity score-matched analysis. Journal of Global Health. 2020; 10 (1): 1-12.

13. Campbell J, Buchan J, Cometto G, David B, Dussault G, Fogstad H, et al. Ressources humaines pour la santé et la couverture sanitaire universelle: promouvoir l'équité et une couverture efficace. Bulletin World Health Organ. 2013;91(11): 853-63.

14. Cotlear D, Nagpal S, Smith O, Tandon A, Cortez R. Going universal. Washington: The World Bank Group. 2015. p. 141-59.

15. Kebijakan Kesehatan Indonesia. Health financing and universal health coverage: compilation of policy notes. Compile Policy Notes. 2015; 253.

16. C L, Rispel, Blaauw D, Ditlopo P, White J. Review Human resources for health and universal health coverage: progress, complexities and contestations; 2018.

17. World Health Organization. Health workforce requirements for universal health coverage and the sustainable development goals. 2016; (17).

18. Adyas A. The role of private insurance in Indonesia in managed care vs indemnity. In Presented in Web-based Course Private Sector Engagement in Health Services: Organized by Center For Policy Studies and Health Service Management Medical Faculty University of Gajah Mada Indonesia (FKKMK UGM) with Asia-Pacific Network for Health System Strengthening (ANHSS); 2020.

19. Perkumpulan Ahli Manajemen Jaminan dan Asuransi Kesehatan Indonesia. Modul dasar-dasar asuransi kesehatan bagian a dan bagian b; 2019.

20. Bakhtiar R. Ketanggapan pemerintah daerah terhadap sasaran tata kelola roadmap jaminan kesehatan nasional tahun 2014 - 2019 di Provinsi Kalimantan Timur. JKKI. 2021; 10 (3).

21. Badan Penyelenggara Jaminan Sosial. BPJS law no. 24 tahun 2011; 2011

22. G B, S S. Managing human resources. 13th edition. Thomson SouthWestern US; 2004

23. Cerf ME. Health worker resourcing to meet universal health coverage in Africa. International Journal of Healthcare Management. 2019; 1-8.

24. Nikoloski Z, McGuire A, Mossialos E. Evaluation of progress toward universal health coverage in Myanmar: a national and subnational analysis. PLoS Med. 2021; 18 (10).

25. Yulianti S, Manuama edit oktavia, Aktariyani T, Marthias T, Trisnantoro L. Optimizing the Role of government in the program area JKN - FK-KMK UGM. JKKI; 2021.

26. Fisher M, Freeman T, Mackean T, Friel S, Baum F. Universal health coverage for non-communicable diseases and health equity: lessons from Australian primary healthcare. IJHPM. 2020; 1-11.

27. Meiriana A, Trisnanto L, Padmawati RS. Implementation of the chronic disease management program (Prolanis) in hypertension at the 
Jetis Health Center, Yogyakarta City. JKKI. 2019; 08 (02): 51-8.

28. Wibisana W. Penguatan sistem pelayanan kesehatan. Kementerian PPN/Bappenas. 2019. p. 1-56.

29. Bustreo F, Doebbler C. Universal health coverage: are we losing our way on women's and children's health? PMNCH; 2019.

30. Verrecchia R, Thompson R, Yates R. Universal health coverage and public health: a truly sustainable approach. Lancet Public Health. 2018; e10-1.

31. Zieff G, Kerr ZY, Moore JB, Stoner L. Universal healthcare in the united states of america: a healthy debate. Medicina (Kaunas). 2020; 56 (11): 1-7.

32. Assefa Y, Hill PS, Gilks CF, Damme W Van, Pas R van de, Woldeyohannes S, et al. Global health security and universal health coverage: understanding convergences and divergences for a synergistic response. PLoS One. 2020; 15 (12).

33. Abuosi AA, Domfeh KA, Abor JY, Nketiah-Amponsah E. Health insurance and quality of care: comparing perceptions of quality between insured and uninsured patients in Ghana's hospitals. International Journal for Equity in Health. 2016; 15 (1): 1-11.

34. Wijayanti L, Nur Z, Laraswati D, Pimada LM. Dampak kebijakan kenaikan iuran BPJS terhadap pengguna BPJS ISOQUANT. Jurnal Ekonomi Manajemen dan Akuntansi. 2020; 4(1): 58-68.

35. Ozawa S, Higgins CR, Yemeke TT, Nwokike JI, Evans L, Hajjou M, et al. Importance of medicine quality in achieving universal health coverage. PLoS One. 2020; 15 (7): 1-15.

36. Shorayasari S, Latief K, Dharmawansyah S. Evaluasi manajemen pelayanan obat pada era JKN di instalasi farmasi Rumah Sakit Medika BSD tahun 2017. Jurnal STIKes IMC Bintaro. 2018; 2 (2): 145-57.

37. Prabowo P, Satibi, Pamudji G. Analisis faktor - faktor yang mempengaruhi ketersediaan obat di era JKN pada rumah sakit umum daerah. Jurnal Manajemen dan Pelayanan Farmasi. 2016; 6 (3): 213-8.

38. Uzochukwu BSC, Okeke C, O’Brien N, Ruiz F, Sombie I, Hollingworth S. Health technology assessment and priority setting for universal health coverage: a qualitative study of stakeholders' capacity, needs, policy areas of demand and perspectives in Nigeria. Global Health. 2020; 16 (1): 1-11.

39. Obermann K, Chanturidze T, Glazinski B, Dobberschuetz K, Steinhauer H, Schmidt JO. The shaded side of the UHC cube: a systematic review of human resources for health management and administration in social health protection schemes. Health Economics Review. 2018; 8 (1).

40. World Health Organization. Global strategy on human resources for health: workforce 2030; 2016.

41. Presiden Republik Indonesia. Undang-Undang Kesehatan no 36 tahun 2014; 2014.

42. Presiden Republik Indonesia. The law on the national social security system (Law No. 40/2004); 2004.

43. Juanita J. Analisis capaian peta jalan JKN di Provinsi Sumatera Utara. JKKI. 2021; 10 (3).

44. Putri PM, Murdi PB. Pelayanan kesehatan di era jaminan kesehatan nasional sebagai program badan penyelenggara jaminan sosial kesehatan. Wacana Hukum. 2019; 25 (1).

45. Marriska K. Strategi kebijakan mengurangi fraud dalam klaim bpjs ditinjau dari permenkes nomor tahun 2015 dihubungkan dengan asas ke- manusiaan. AKTUALIA. 2020; 3 (1): 673-87.

46. Suhud H. An audit of knowledge and attitude regarding implementation of the national health insurance (JKN) in BPK RI. The International Journal of Multicultural and Multireligious Understanding (IJMMU). 2019; 6 (5).

47. Joarder, Taufique, Chaudhury, Z T, Mannan, Ishtiaq. Universal health coverage in Bangladesh: activities, challenges, and suggestions. Psyche (Camb Mass); 2019: 2019: 4954095.

48. Tomoko K. Human resources of health for universal health coverage in Japan: in the era of COVID-19. Journal of the National Institute of Public Health. 2021; 70 (1): 13-21.

49. Zalani GS, Khalilnezhad R, Mirbahaeddin E, Shokri A, Kashkalani T, Bayat M. Human resources for health strategies: the way to achieve universal health coverage in the Islamic Republic of Iran. The Eastern Mediterranean Health Journal. 2018; 24 (9): 846-54.

50. Mukti AG. Pengenalan indikator kinerja untuk peningkatan mutu layanan kesehatan. BPJS Kesehatan kenalkan kinerja kepada rumah sakit. BPJS: Media info BPJS kesehatan edisi 101; 2017.

51. Adyas A. Strategi rekonstruksi kurikulum mendukung sertifikasi lulusan D3 askes. In Poltekkes Malang: Presented in the Workshop Evaluasi dan Pengembangan Kurikulum dalam Rangka Implementasi Blended Learning dan Pembelajaran Praktikum Bidang Kesehatan di Era Normal Baru; 2021.

52. Azeez YO, Babatunde YO, Babatunde D, Olasupo J, Alabi E, Bakare $\mathrm{P}$, et al. Towards universal health coverage: an analysis of the health insurance coverage in Nigeria. International Journal of Health and Life Sciences. 2021; 7 (3).

53. Park J. Medicaid managed care enrollments and potentially preventable admissions: an analysis of adult Medicaid recipients in Florida. International Journal of Healthcare Management. 2021; 14 (3): $771-$ 80.

54. Obermann K, Jowett M, Kwon S. The role of national health insurance for achieving UHC in the Philippines: a mixed-methods analysis. Global Health Action. 2018; 11 (1).

55. Kipo-Sunyehzi DD, Ayanore MA, Dzidzonu DK, Ayalsumayakubu Y. Ghana's journey towards universal health coverage: the role of the national health insurance scheme. European Journal of Investigation in Health, Psychology, and Education. 2020; 10 (1): 94-109.

56. Sumriddetchkajorn K, Shimazaki K, Ono T, Kusaba T, Kobayashi N. Universal health coverage and primary care, Thailand. Bulletin World Health Organization. 2019; 97 (6): 415-22.

57. Rismawan R, Ayu D, Padmawati RS. Kebijakan pembiayaan jaminan kesehatan Pemerintah Kota Palu di era jaminan kesehatan nasional. Jurnal Kebijakan Kesehatan Indonesia. 2018; 07 (04): 178-89..

58. Gostin LO. The legal determinants of health: how can we achieve universal health coverage and what does it mean? International Journal of Health Policy and Management (IJHPM). 2021; 10 (1): 1-4.

59. Perehudoff K. Universal access to essential medicines as part of the right to health: a cross-national comparison of national laws, medicines policies, and health system indicators. Global Health Action. 2020; 13 (1).

60. Prince R. Universal health coverage in the global south: new models of healthcare and their implications for citizenship, solidarity, and the public good. 2017 p. 153-72. 
Adyas. The Indonesian Strategy to Achieve Universal Health Coverage through National Health Insurance System: Challenges in Human Resources

61. Nygren-Krug H. The right(s) road to universal health coverage. Health and Human Rights Journal. 2019; 21 (2): 215-28.

62. Chemouni B. The political path to universal health coverage: power, ideas and community-based health insurance in Rwanda. World Development. 2018; 106: 87-98.

63. Smithi A, Ranchodii S, Strugnellii D, Wishniaii J. Human resources for health planning and National Health Insurance: the urgency and the opportunity. 2018; (1): 23-32.

64. Squires N, Colville SE, Chalkidou K, Ebrahim S. Medical training for universal health coverage: a review of Cuba - South Africa collabora- tion. 2020; 9: 1-10.

65. Tao W, Zeng Z, Dang H, Lu B, Chuong L. Towards universal health coverage: lessons from 10 years of healthcare reform in China. BMJ Global Health. 2020; 1-9.

66. Hendarwan H, Savithri Y. A case study on the implementation of local health insurance benefit packages. A case study implement local Health Insurance Benefit Package. 2015; 17 (4): 327-36. 